\title{
Az igazságosság és a besorolás etikai problémái az egészségügyben, különös tekintettel a COVID-19-járvány olaszországi tapasztalataira
}

\author{
Péter Orsolya Márta dr. \\ Semmelweis Egyetem, Általános Orvostudományi Kar, Magatartástudományi Intézet, Budapest
}

\begin{abstract}
A 2020. év elején kirobbant COVID-19-világjárvány többek között ráirányította a figyelmet az életmentő-életfenntartó kezelések igazságos elosztásának érzékeny kérdésére is. Európán belül elsőként Olaszországot sújtotta a katasztrófa, a válsághelyzetben pedig az érzéstelenítés, fájdalomcsillapítás, újraélesztés és intenzív ellátás területén tevékenykedő szakemberek olasz társasága, a SIAARTI 2020. március 6-án közzétett egy 15 pontos ajánlást. E szerint utilitarista megközelítéssel a rendelkezésre álló szúkös erőforrásokat azon betegek kezelésére kellene fordítani, akik túlélési esélye nagyobb, valamint több életévre számíthatnak a jövőben, mert ez biztosíthatja a lehető legtöbb ember számára a lehető legnagyobb hasznot. A javaslat komoly szakmai vitát robbantott ki, amely egyértelmúvé tette, hogy az orvosi eszközök igazságos elosztására vonatkozó diskurzust feltétlenül folytatni kell, nemcsak Olaszországon belül, hanem a pandémiától sújtott többi államban is.
\end{abstract}

Orv Hetil. 2020; 161(45): 1899-1907.

Kulcsszavak: COVID-19, orvosi etika, besorolás, szelekciós kritériumok, Olaszország

\section{COVID-19 and the ethical issues of justice and rationing in health care, with particular regard to the Italian experience}

\begin{abstract}
Among other queries, the explosion of the COVID-19 pandemic at the beginning of 2020 has firmly put in focus the sensitive issue of how to allocate scarcely available life-saving treatments in a fair and just manner. The first European country to face an emergency caused by the pandemic was Italy. In a rapidly escalating crisis, on 6th March 2020, the Italian Society of Anaesthesia, Analgesia, Resuscitation, and Intensive Care (SIAARTI) issued a series of 15 recommendations, suggesting that a utilitarian approach should be adopted in Italian health care and the extremely scarce resources should be reserved for patients with a greater probability of survival and life expectancy, in order to maximize the benefits for the largest possible number of people. The recommendations generated a heated debate among health care professionals, thereby evidencing that similar discussions must be initiated and pursued in all countries affected by the pandemic.
\end{abstract}

Keywords: COVID-19, medical ethics, health care rationing, selection criteria, Italy

Péter OM. [COVID-19 and the ethical issues of justice and rationing in health care, with particular regard to the Italian experience]. Orv Hetil. 2020; 161(45): 1899-1907.

(Beérkezett: 2020. augusztus 25.; elfogadva: 2020. szeptember 4.)

\section{Rövidítések}

COVID-19 = (coronavirus disease 2019) koronavírus-betegség 2019; EED Project $=($ European Emergency Data Project $)$ 2000-ben létrehozott, majd az Európai Bizottság által finanszí- rozott (SPC 2002) kutatási együttmúködési hálózat, amely egy egyesült államokbeli partnerrel együttmúködve 2004-ig 12 európai országban (Ausztria, Belgium, Dánia, Egyesült Királyság, Finnország, Franciaország, Írország, Németország, Olasz- 
ország, Portugália, Spanyolország, Svédország) vizsgálta a sürgősségi ellátási rendszerek múködését; EU = Európai Unió; FNOMCeO $=($ Federazione Nazionale degli Ordini dei Medici Chirurgi e degli Odontoiatri) Orvosi és Fogorvosi Kamarák Nemzeti Szövetsége (Olaszország); FNOPI = (Federazione Nazionale degli Ordini delle Professioni Infermieristiche) Ápolói Kamarák Nemzeti Szövetsége (Olaszország); OHPIP = (Ontario Health Plan for an Influenza Pandemic) Ontario tartományban 2008-ban bevezetett, influenzapandémia esetén követendő orvosi protokoll (Kanada); QALY = (quality-adjusted life year) életminőséggel korrigált életév, amelynek számítása során a várható életéveket az életminőséggel súlyozzák; SARS-CoV-2 = (severe acute respiratory syndrome coronavirus 2) súlyos akut légzőszervi tünetegyüttest okozó koronavírus-2; SIAARTI $=($ Società Italiana di Anestesia, Analgesia, Rianimazione e Terapia Intensiva) Olasz Aneszteziológiai, Analgesiás, Reanimációs és Intenzív Terápiás Társaság (Olaszország); SIGG $=($ Società Italiana di Gerontologia e Geriatria) Olasz Gerontológiai és Geriátriai Társaság (Olaszország); SIGOT = (Società Italiana di Geriatria Ospedale e Territorio) kórházi és otthonápolási területen dolgozó geriáter szakemberek társasága (Olaszország); SOFA = (sequential organ failure assessment) a szekvenciális szervi elégtelenség értékelése; WHO = (World Health Organization) Egészségügyi Világszervezet

Tedros Adhanom Ghebreyesus, a WHO fötitkára, 2020. március 11-én megtett bejelentésében [1] pandémiának nyilvánította a SARS-CoV-2-járványt, egyben figyelmeztetett arra, hogy „eddig még sobasem láttunk olyan világjárványt, amelyet koronavirus robbantott volna ki”. Felhívta továbbá a figyelmet arra, hogy a járvány elleni küzdelemben egyes országok már kapacitáshiánytól, mások forráshiánytól szenvednek. E kapacitás- és forráshiány jól ismert probléma az egészségügyi ellátásban, hiszen nincsen a világon olyan ország, ahol a nemzeti jövedelem növekedése meghaladná az egészségügyi kiadások növekedésének ütemét [2]. Nincsen tehát a világon olyan ország, amely képes volna teljes mértékben kielégíteni az egészségügyi szektor pénzügyi igényeit, az egészségügy minden országban - annak gazdagságától függetlenül lényegében alulfinanszírozott, a betegellátás során pedig az eszköz- és forráshiány valamely formáját az orvosok és a betegek egyaránt megtapasztalják. A helyzetet tovább nehezíti az, hogy a gyógyító tevékenység „humánerőforrásai”, az orvosok, ápolók és más egészségügyi szakdolgozók sem állnak korlátlan létszámban rendelkezésre, más sajátos „eszközök” pedig még a leggazdagabb országokban is limitáltak - gondoljunk csak a transzplantációra alkalmas emberi szervekre, amelyeket még a XXI. században sem sikerült mesterséges úton, például múszervekkel maradéktalanul kiváltani [3].

\section{„Ki fog élni? Ki fog meghalni?” - elvek és kritériumok a besorolásban}

Jobn Frederic Kilner 1990-ben publikált könyvének [4] fenti címe drámaian sommázza a korlátozott mennyiségben rendelkezésre álló egészségügyi erőforrások elosztá- sával kapcsolatos legsúlyosabb etikai probléma lényegét. A nem életmentő orvosi beavatkozásra történő hosszas várakozás már az alapellátásban is komoly frusztrációt jelent a betegek számára [5] - de mi történjen akkor, ha várakozásra korlátozottan vagy egyáltalán nincsen lehetőség, mert a végrehajtandó beavatkozás életmentő jellegü, viszont az erre szoruló személyek száma meghaladja a rendelkezésre álló kapacitást? Hogyan dönthetünk részrehajlás nélkül, pártatlanul és igazságosan egy ilyen helyzetben? Sőt, egyáltalán lehetséges-e az ilyen jellegű döntéshozatal? Az egyik kérdés tehát az, hogy amikor a modern „nyugati” orvosi etika egyik sarkalatos alapelvének, az igazságosságnak [6] a jegyében megpróbálunk rangsort felállítani a várakozó emberek között, vajon milyen módon értelmezzük az „igazságosság” mibenlétét. A másik kérdés az, hogy ugyanezen rangsort milyen konkrét szempontok alapulvételével hozhatjuk létre a gyakorlatban.

\section{A materiális igazságosság különböző lehetséges értelmezései az egészségügyben}

Az egészségügyi erőforrások elosztása kapcsán a szakirodalomban számos vélemény és javaslat található arra nézve, hogy tartalmi lényegét tekintve miként kellene értelmeznünk az ,igazságosság”-ot. A kérdéssel foglalkozó múvek mennyisége átfoghatatlanul nagy; ez is mutatja, hogy a kérdés mennyire nehezen értelmezhetó, vitatott és bonyolult. A komplex elemzés igényéról lemondva, valamint a problémát jelentősen leegyszerúsítve az igazságosságértelmezéseket három fó kategóriába sorolhatjuk:

(a) A szükségleteket középpontba helyező értelmezések, amelyek szerint az egészségügyben rendelkezésre álló erőforrásokat valamilyen jogosnak ítélt szükséglet, igény alapján kell elosztani a jelentkezők között.

(b) A valamilyen hasznot maximalizálni igyekvő értelmezések, amelyek szerint az egészségügyi erőforrásokat úgy kell elosztani a jelentkezők között, hogy az valamilyen területen a lehető legtöbb hasznot eredményezze.

(c) Az egalitáriánus - az egyenlőséget középpontba helyező - értelmezések, amelyek közös kiindulópontja az, hogy minden ember élete egyenlő értékú, illetve amelyek szerint az erőforrások elosztása során a jelentkezők között valamilyen formában fennálló (például gazdasági) egyenlőtlenséget mérsékelni kell [7].

Ezen túl nem kizárt az sem - sőt többek szemében kifejezetten kívánatos -, hogy a fenti értelmezések valamilyen kombinációjával, integrált módon próbáljunk meg törekedni az igazságosság megvalósítására [8].

A klinikai gyakorlatban alapvetően az (a) kategóriába sorolható értelmezés van jelen, amikor a „szükséglet”-et a kezelőorvos által szakmai szempontok szerint megállapított ellátásra vonatkozó igényként interpretálják; tehát az ellátásra váró betegnek arra az orvosi beavatkozásra van szüksége, amelyet számára a szakember megállapít.

A (b) kategóriába tartozó, utilitarista interpretációk szerint az igazságosság az egészségügyi erőforrások 
olyan módon történő elosztását jelenti, amely a lehető legkedvezőbb eredménnyel jár. Sokak számára mindez azt jelenti, hogy az adott ország lakosságának (különböző módszerekkel mért) általános egészségi állapota, életminősége a lehető legjobb legyen, tehát az igazságosság kérdését a közösség szintjéről szemlélik. E megközelítés ugyanakkor azt is implikálja, hogy az erőforrások elosztása során azt az egyént kell előnyben részesíteni, akinek megmentése a közösség számára a legnagyobb, jellegzetesen pénzben (is) kifejezhető haszonnal jár. A hasznok kalkulálása rendszerint különböző költséghasznossági elemzési módszerekkel történik (közülük a legismertebb a QALY), de természetesen ezek a számítási módszerek is számos etikai problémát vetnek fel [9].

Az egészségügyi ellátásról folytatott szakmai és laikus diskurzusokban a (c) kategóriába tartozó, egyenlőséget hangsúlyozó és egyenlőtlenségeket tompítani kívánó megközelítések bukkannak fel a leggyakrabban. Ezek szerint - tekintettel az emberi életek morális értelemben vett egyenrangúságára - mindenkinek joga van legalább ahhoz, hogy az egészségügyben hozzáférjen egy elfogadható mértékű, tisztességes minimumellátáshoz [10]. Emellett vannak olyanok, akik arra hivatkoznak, hogy mindenkinek jár egyfajta méltányosan hosszú, természetes élettartam (ez az ún. „fair innings”-érvelés) [11], ugyanakkor vannak, akik azt hangsúlyozzák, hogy az igazságos elbánáshoz elegendő az is, ha mindenkinek egyenlő módon csak esélyt adunk arra, hogy egészséges életet élhessen [12].

\section{A besorolás lehetséges kritériumai}

Kilner a korábban idézett múvében négy csoportra osztja azokat a - szakirodalomban és a gyakorlatban korábban megjelent - lehetséges kritériumokat, amelyek alkalmazását mások a korlátozott mennyiségű egészségügyi erőforrások elosztása kapcsán már felvetették; ezt követően mindegyik kritériumra nézve ismerteti azokat az érveket és ellenérveket, amelyeket etikai szempontból az adott szelekciós kritérium mellett és ellenében felhozhatunk, majd megkísérli egy etikailag elfogadható, kompromisszumos nézet kialakítását. Mindez természetesen csak egy lehetséges javaslatot jelent a sok közül. Az elképzelhető besorolási kritériumok körének megállapítására és etikus mivoltára vonatkozó viták 1990 óta mit sem vesztettek intenzitásukból, az ezzel kapcsolatos szakirodalmi múvek köre éppen olyan határtalanul gazdag és sokrétü, mint az igazságosságkoncepciók esetében, és - mint ahogyan azt a koronavírus-pandémia kapcsán kirobbant, a későbbiekben ismertetendő olasz vita is mutatja - ugyanígy nem remélhetjük, hogy e kérdésben mindenki számára elfogadható megoldás a belátható jövőben bármikor is megszülessen.

A Kilner-féle rendszer a következők szerint épül fel:

a) Társadalmi-szociális kritériumok

- A megmentendő beteg társadalmi hasznossága, értékessége (social value).
- Valamely, területileg vagy társadalmilag előnyben részesített csoporthoz való tartozás, például egy bizonyos területen belül élők köre, kiskorú gyermekek, veterán katonák (favored group).

- A beteg megmentéséhez szükséges egészségügyi erőforrások nagysága (resources required).

- A megmentendő személyt mások irányában terhelő különleges kötelezettségek („nélkülözhetetlenség”), például a kezelendő beteg által eltartott kiskorú gyermekek léte, speciális orvosi szaktudás (special responsibilities).

b) Szociomedikális kritériumok

- Életkor (age).

- Pszichés állapot/stabilitás (psychological ability).

- Támogató környezet (supportive environment).

c) Orvosi kritériumok

- A kezelés orvosi haszna (medical benefit).

- Közvetlen életveszély (imminent death).

- A kezelés hasznosságának/sikerességének valószínúsége (likelihood of benefit).

- A kezeléssel megmenthető életévek száma/a kezelés pozitív hatásainak tartóssága (length of benefit).

- A kezelés utáni élet minősége (quality of benefit).

d) Egyéni (individuális) kritériumok

- A beteg közremúködési hajlandósága saját gyógyulásában, egészsége megőrzésében (willingness).

- Fizetőképesség (ability to pay).

- Véletlenszerü kiválasztás/sorsolás (random selection).

\section{Orvosszakmai döntéshozatal szülkséghelyzetben: a betegek osztályozása (triage, triázs)}

A gyakorlati betegellátás oldaláról megközelítve természetesen feltehetjük azt a kérdést, hogy vajon az életmentő orvosi eszközök elosztásának összetett és megterhelő feladata kapcsán egyáltalán beengedhetünk-e a döntési folyamatba nem szigorúan orvosszakmai kritériumokat is. Szintén több évszázados történelemmel rendelkező erőfeszítések mutatják, hogy a gyakorlatban dolgozó, hippokratészi esküjük által vezérelt orvosok komplex szakmai szempontrendszerek alapján próbálták és próbálják meghatározni azt, hogy az azonos időben jelentkező számos rászorult között miként osszák el a legmegfelelőbben a korlátozott mennyiségben rendelkezésre álló életmentő eszközöket. Ennek talán legrégebbi példája az úgynevezett triázs ( „triage”, a francia "trier” = választani, szétválogatni igéből) megszületése.

Bár az orvoslás története hagyományosan DominiqueJean Larrey-t, Napóleon katonai fósebészét tartja a triázs „szülőatyjának”, aki a katonákat sebesülésük súlyossága alapján részesítette ellátásban [13], a triázseljárás első szabályainak egyértelmű rögzítése 1925-re datálódik, amikor két magas rangú francia katonaorvos, Charles Spire és Pierre Lombardy megjelentette az egészségügyi 
ellátórendszer háborús időkben történő megszervezését és múködtetését tárgyaló kézikönyvét [14].

A Spire és Lombardy által négy pontban megállapított betegosztályozás lépései a következők voltak: (1) a sebesülés diagnosztizálása; (2) az ellátás sürgősségének megállapítása; (3) a szállíthatóság mértékének megállapítása; (4) azon célhelyszín meghatározása, ahová a sebesültet kezelésre el kell szállítani [14]. A felállított rendszerre természetesen rányomta bélyegét a különleges alkalmazási helyzet, a csatatéren megsebesült katonák ellátásának megszervezése, az eljárás célja pedig az volt, hogy a lehető leghatékonyabb módon a lehető legtöbb katona életét mentsék meg - természetesen azért, hogy a gyógyult katonák mihamarabb folytathassák a hadmúveletekben történő részvételt [15].

Az eredetileg háborús helyzetre kifejlesztett betegosztályozási eljárás gondolatát a polgári medicina is átvette az Egyesült Államokban, majd az Egyesült Királyságban és Európa más országaiban is, mégpedig egy olyan területen, amely békeidőben talán a leginkább emlékeztet a harctéri körülményekre: a sürgősségi betegellátás területén. Ugyanakkor az egyes országokban alkalmazott betegosztályozási szempontok jelentős eltéréseket mutatnak [16], és még az Európai Unión belül sem alakult ki valamiféle egységes szempontrendszer vagy szabályozás. Az EU-ban először a 2000. év során indult egy kutatási projekt (az úgynevezett EED Project), négy európai nagyvárosban múködő sürgősségi ellátórendszer múködésének feltérképezésére és összehasonlítására. A projekt 2002-ben az Európai Bizottság által finanszírozott kutatási együttmúködési hálózattá bővült, amely 2004-ig 12 európai országban vizsgálta a sürgősségi ellátási rendszerek múködését [17]. A kutatás célja olyan közös elemek és indikátorok (mint például a válaszidők hossza vagy a 100 ezer lakosra eső munkaórák száma) meghatározása volt, amelyek lehetővé tették a sürgősségi betegellátási rendszerek hatékonyságának vizsgálatát [18]. A kutatás etikai kérdésekre nem terjedt ki, ahogyan a WHO 2008as, az EU tagállamait átfogó, ugyanilyen tárgyú vizsgálata sem [19].

\section{Amikor az orvosszakmai szempontok már nem elegendőek - Ontario állam influenzapandémiára kidolgozott protokollja}

A Torontói Egyetem Bioetikai Központja 2014-ben azt a felkérést kapta, hogy munkatársaik dolgozzanak ki olyan kiegészítő szelekciós kritériumokat, amelyek akkor kerülhetnének alkalmazásra, ha egy jövőbeli járvány esetén az Ontario tartományban már 2008-ban bevezetett (majd később módosított), influenzapandémia esetén követendő protokoll (OHPIP) [20] szerint intenzív terápiás ellátásra szoruló betegek létszáma meghaladná a rendelkezésre álló erőforrásokat.
Az OHPIP jelenleg hatályos verziója három lépésben állapítja meg a triázs folyamatát: (1) a betegek túlélési valószínúség alapján történő besorolása, a sürgősségi ellátást indokoló orvosi kritériumok alkalmazásával; (2) az így kiválasztott betegek köréból bizonyos betegeknek a kizárási kritériumok (például metasztatizált malignus tumor) alkalmazásával történő kizárása; (3) a sürgősségi ellátásra indokoltan szoruló betegek állapotának klinikai értékelése a SOFA használatával. A betegeket a fentiek alapján négy színkóddal jelölt csoportba sorolják: a kék kóddal jelölt betegek nem részesülnek intenzív terápiás ellátásban, őket szokványos orvosi vagy palliatív kezelésben kell részesíteni; a piros kóddal jelölt betegek élvezik a legmagasabb prioritást az intenzív terápiás osztályra való bejutás és a lélegeztetőgépre kapcsolás szempontjából; a sárga kóddal jelölt betegek közepes prioritást élveznek, míg a zöld kóddal jelöltek elég jól vannak ahhoz, hogy ne részesüljenek intenzív terápiás ellátásban [21].

A feladatra létrehozott speciális munkacsoport 13 lehetséges szempontot nevezett meg (mint például az érkezési sorrend, a beteg társadalmi hasznossága vagy rászorultsága), majd a kritériumokat online kérdőív formájában véleményeztették orvosokkal, bioetikusokkal, kutatókkal és közösségi vezetőkkel. A kérdőívek kiértékelését követően a munkacsoport arra a következtetésre jutott, hogy etikailag összesen két szempont volna a gyakorlatban is megfelelő módon alkalmazható: az érkezési sorrend (a „first come first served” elv), valamint a random módon történő kiválasztás, sorsolás. A munkacsoport úgy vélte, hogy az OHPIP kifejezetten utilitarista, SOFA-pontszámokkal mérő jellegét ez a két, egalitáriánus jellegű szelekciós kritérium tudná megfelelően ellensúlyozni, továbbá ez a két kritérium bármely más triázsprotokollban is etikailag védhető „biztonsági szelepként” múködhetne [22].

\section{Egy hipotetikus helyzet aktuálissá válása: a COVID-19-járvány kitörése Olaszországban}

A COVID-19-világjárvány a 2014-ben Ontarióban még hipotetikusként kezelt helyzetet ijesztő sebességgel tette valóssá, amikor a modern kor eddig talán legkatasztrofálisabb pandémiája elérte Olaszországot.

Az európai országok közül Olaszországban az első igazolt koronavírus-megbetegedést 2020. január 30-án egy Wuhanból érkezett idős kínai turistapáron diagnosztizálták, a fertőző betegségekre szakosodott római "Lazzaro Spallanzani” kórházban [23].

$\mathrm{Az}$ olasz Egészségügyi Minisztérium koronavírust monitorozó honlapján feltüntetett adatok szerint az első másodlagos fertőzéses esetet 2020. február 18-án diagnosztizálták Lombardiában, a Lodi megyében található Codogno nevű kisvárosban [24]. Ezt követően Lombardia tartomány rendkívüli sebességgel vált az új típusú koronavírus, a SARS-CoV-2 (COVID-19) által okozott 
megbetegedések első európai gócpontjává, majd 2020. március 8-ra Olaszország - Kínát követve - második lett a járványtól leginkább sújtott országok sorában.

A kórházon belüli triázsra vonatkozó, jelenleg hatályos és az egész országban érvényesülő irányelveket (Linee di indirizzo nazionali sul triage intraospedaliero”) [25] 2019-ben hirdette ki az olasz Egészségügyi Minisztérium. A szokványos körülmények között múködő sürgősségi ellátásban az ellátásra várakozókat öt színkóddal jelölt csoportba sorolják: fehér (gyors ellátást nem igénylő esetek) legfeljebb 240 percnyi várakozási idővel; zöld (stabil állapotú beteg, hirtelen állapotromlás veszélye nélkül) legfeljebb 120 percnyi várakozási idővel; kék (stabil állapotú beteg, akinek azonban állapota szenvedéssel, valamint a hosszú távú egészségromlás veszélyével jár) legfeljebb 60 percnyi várakozással; narancssárga (az alapvető vitális funkciókat potenciálisan kompromittáló állapot, a hirtelen állapotromlás veszélyével) legfeljebb 15 perc várakozással; végül pedig a vörös (egy vagy több vitális funkció megszünése vagy közvetlen kompromittálódása) azonnali ellátási kötelezettséggel.

2020. február 18-át követően az észak-olaszországi és különösen a lombardiai kórházakat rövid időn belül elárasztották a narancssárga, illetve vörös kóddal jelölt be- tegek. A helyzet olyan gyorsan vált rendkívüli mértékben kritikussá, hogy az érzéstelenítés, fájdalomcsillapítás, újraélesztés és intenzív ellátás területén tevékenykedő szakemberek olasz társasága, a SIAARTI hétfös, Marco Vergano által irányított munkacsoportja 2020. március 6-án, tehát 17 (!) nappal később közzétett egy dokumentumot „Az intenzív terápiás ellátásba történő felvételre, valamint az intenzín terápiás ellátás felfüggesztésére vonatkozó klinikai etikai ajánlások, az igények és a rendelkezésre álló erôforrások közötti kivételes aránytalanság fennállásának esetén” címmel [26-28].

A dokumentum 15 pontba szedve fogalmazza meg az ajánlásokat, amelyeket - a szerzók véleménye szerint legfeljebb csak természeti katasztrófához hasonlítható helyzetben - alkalmazni javasolnak az intenzív terápiás ellátásban (1. táblázat) [28]. Pontosabban szólva, a COVID-19 által kiváltott helyzet még egy katasztrófánál is súlyosabb: egy földrengés vagy közúti tömegbaleset helyileg és időben lehatárolt, valamint az orvosi ellátásra szorulók száma is becsülhetően véges, az új típusú koronavírus viszont az idő múlásával folyamatosan terjed, a megbetegedettek (és ezen belül az intenzív terápiás ellátásra szorulók) köre gyorsan és exponenciálisan növekszik, a pandémia vége és a fertőzöttek végleges

1. táblázat $\mid$ Az Olasz Aneszteziológiai, Analgesiás, Reanimációs és Intenzív Terápiás Társaság (SIAARTI) klinikai etikai ajánlásai az intenzív terápiás ellátásba történő felvételre, valamint az intenzív terápiás ellátás felfüggesztésére vonatkozóan, az igények és a rendelkezésre álló erőforrások közötti kivételes aránytalanság fennállásának esetén - összefoglalás

\begin{tabular}{|c|c|}
\hline $\begin{array}{l}\text { Az intenzív terápiás osztály } \\
\text { erőforrásainak elosztása }\end{array}$ & $\begin{array}{l}\text { Az intenzív terápiás osztály erőforrásainak elosztása komplex és érzékeny feladat. A korlátozott mennyiségben } \\
\text { rendelkezésre álló erőforrások elosztásának kritériumait rugalmasan, az adott helyszínen fennálló helyzet teljes } \\
\text { körű figyelembevételével kell megállapítani. }\end{array}$ \\
\hline $\begin{array}{l}\text { A triázs alapelvei és } \\
\text { szempontjai }\end{array}$ & $\begin{array}{l}\text { Minden, kritikus állapotban lévő beteg életkorát, fennálló más betegségeit és funkcionális státuszát nagyon gon- } \\
\text { dosan kell mérlegelni. Eleve rossz állapotú, idősebb betegek esetén hosszabb, emiatt több eróforrást lekötő ke- } \\
\text { zelésre lehet számítani, míg az egyébként egészséges, fiatalabb páciensek esetén rövidebb kezelési időt és sikeres } \\
\text { kezelést valószínúsíthetünk. A rendelkezésre álló szűkös erőforrásokat azok kezelésére kell fordítani, akik túlélési } \\
\text { esélye nagyobb, valamint több életévre számíthatnak a jövőben; ez biztosíthatja a lehető legtöbb ember számá- } \\
\text { ra a lehető legnagyobb hasznot. Az érkezési sorrendben történő betegellátás nem javasolt, mert ez azt okozná, } \\
\text { hogy egyébként potenciálisan jól gyógyítható, de az intenzív terápiás osztály megteltét követően érkező bete- } \\
\text { gektől kellene megtagadni az ellátást. }\end{array}$ \\
\hline
\end{tabular}

Előzetes rendelkezések A betegek egészségügyi ellátására vonatkozó előzetes rendelkezéseket, élő végrendeleteket különös körültekintéssel kell figyelembe venni, s azok tartalmáról lehetóleg magával a beteggel, a beteg képviselójével, családtagjaival, valamint az egészségügyi ellátószemélyzet tagjaival is konzultálni kell. Ha előzetes rendelkezéssel bíró beteget nem részesítenek intenzív terápiás kezelésben, mindezt körültekintően kell dokumentálni és kommunikálni.

Döntéshozatali eljárás $\quad$ Az életfenntartó kezelés megtagadását vagy az elkezdett kezelés abbahagyását feltétlenül meg kell vitatni az egészségügyi ellátószemélyzet tagjaival, lehetőség szerint pedig magával a beteggel és/vagy képviselőjével is. Különösen komplex vagy egyébként problémás esetekben másodvéleményt célszerü kérni.

Palliatív ellátás Az életfenntartó kezelés megtagadását vagy az elkezdett kezelés abbahagyását követóen a hypoxaemiás beteget feltétlenül megfelelő palliatív kezelésben kell részesíteni, a vonatkozó nemzeti vagy nemzetközi ajánlásokkal összhangban.

Az intenzív terápiás osztályon Az életfenntartó kezelés szükségességét naponta újra kell értékelni. Ha egy beteg nem reagál a hosszabb ideje történő ellátás és a kezelés tartó intenzív terápiás kezelésre, vagy ha súlyos klinikai komplikációk lépnek fel, a szúkös erőforrások optimális arányossága kihasználása érdekében nem szabad halogatni a terápia abbahagyására vonatkozó döntéshozatalt.

Kapcsolattartás

és a családtagokról történő gondoskodás
A klinikai tapasztalatok megosztása érdekében az egészségügyi dolgozók közötti kapcsolattartás elengedhetetlen. Időt és erőforrásokat kell szánni a dolgozók tájékoztatására, valamint folyamatosan figyelni kell, mutatnak-e kiégésre vagy erkölcsi válságra utaló jeleket. Figyelmet kell fordítani továbbá arra, hogy a korlátozott látogatási lehetőség milyen hatással van a betegek képviselőire és családtagjaira, ezen belül pedig különösen nagy figyelmet kell szentelni annak az esetnek, ha egy beteg a teljes látogatási tilalom során huny el. 
száma pedig nem jósolható meg előre . Ebben a helyzetben - vélekednek a szerzők - speciális besorolási-elosztási kritériumok alkalmazása indokolt, hiszen a rendkívüli körülmények között az intenzív terápiás ellátást nem lehet biztosítani minden rászoruló számára, az élet védelmének elve nem érvényesülhet korlátlanul, és az orvosok nem teljesíthetik maradéktalanul az életmentő kezelés megadása vonatkozásában őket terhelő etikai és jogi kötelezettségüket.

E döntéshozatalt tovább nehezíti, hogy az olasz Alkotmánybíróság a 2002-ben kelt, 282. számú határozatában [29] már kimondta: nem a jogalkotó feladatát képezi annak pontos meghatározása, hogy az orvoslásban mely terápiás eljárásokat lehessen alkalmazni, milyen korlátokkal és milyen feltételekkel. A gyógyító gyakorlat a rendkívül gyorsan fejlődő-változó tudomány eredményeire támaszkodik, így a zsinórmértéket csak az adott orvos autonóm és felelős döntése képezheti, aki a rendelkezésre álló aktuális tudásanyag alapján határozza meg az alkalmazandó kezelést. Mindebből az is következik, hogy az olasz jogalkotónak (egyelőre?) nem áll szándékában valamiféle besorolási kritériumrendszer törvényi rögzítése, mert az ilyen szabályok úgymond „kőbe vésése" rugalmatlanná tenné az orvosi döntési folyamatot, ellehetetlenítené az orvostudomány gyors fejlődéséhez való naprakész alkalmazkodást, valamint az egyéniesített döntést. Az ellátandó betegek besorolása tehát orvosi feladat marad, a SIAARTI ajánlásainak egyik deklarált célja pedig az, hogy az igények és a rendelkezésre álló erőforrások közötti kivételes aránytalanság esetén olyan szakmai és morális támpontokat adjon a határozásra kényszerülő klinikusok számára, amelyek segíthetik a rendkívül nehéz és megterhelő döntéshozatalt.

A probléma egy újabb összetevője továbbá az, hogy tradicionális módon Olaszországban az élet védelmének orvosi kötelezettsége morálisan rendkívül erős, ebben pedig jelentős szerep jut az élet szentségét képviselő katolikus egyháznak. Egészen a közelmúltig az életvégi döntésekről kezdeményezett szinte minden vita a katolikus egyház markáns részvételével zajlott, és lényegi elörelépés nélkül halt el [30]. Míg az 1997-es magyar egészségügyi törvény - ha korlátozásokkal is - de már lehetővé tette a beteg számára az életmentö-életfenntartó kezelés visszautasítását és az élő végrendelet („living will”) készítését, az olasz parlament 2017. december 14én (!) fogadta el a 219/2017. számú, 2018. január 31én hatályba lépett törvényt [31], amely Olaszországban első alkalommal mondta ki, hogy egy nagykorú, cselekvőképes személynek joga van előzetes rendelkezéssel visszautasítani a jövőben esetleg szükségessé váló életmentő-életfenntartó beavatkozásokat. Nem meglepő, hogy az olasz szakmai közösség egyetérteni látszik a következőkben: bár nagyon sokan üdvözölték a jogszabály megalkotását, időre, valamint az orvostársadalom és a laikusok közötti sokrétű párbeszédre van szükség ahhoz, hogy az új jogszabályt konfliktusok nélkül alkalmazhassák a gyakorlatban [32].
Úgy tünik, hogy a támpontok megfogalmazása során a SIAARTI szerzői úttörő módon megkíséreltek egyfajta egyensúlyi helyzetet kreálni a döntéshozatalt jelenleg irányító, az igazságosság egalitáriánus megközelítésén és az emberi élet védelmén nyugvó orvosszakmai szempontok, valamint az igazságosság haszonmaximalizálásra törekvő megközelítése között [33] - pontosabban szólva arra hívták fel a figyelmet, hogy meg kell barátkoznunk a gondolattal: rendkívüli krízishelyzet esetén az egalitáriánus megközelítés helyébe az utilitarista megközelítésnek kell(ene) lépnie. A COVID-19-pandémiát megelőzően az intenzív ellátásba történő bekerülés érkezési sorrendben, a fentiekben már ismertetett triázs szabályai szerint, azon alapelv tiszteletben tartásával történt, miszerint minden rászorulónak meg kell kapnia az orvosilag indokolt kezelést - az ijesztő gyorsasággal kirobbant járvány azonban egyértelmúvé tette, hogy ez a sarkalatos szabály a gyakorlatban többé már nem valósítható meg maradéktalanul. Ezen túl, sajnálatos módon - ahogyan március óta a világ más országaiban, így például Spanyolországban, az Egyesült Államokban vagy Brazíliában bekövetkezett események is alátámasztják - úgy tûnik, hogy a COVID-19-pandémia nem marad meg egyszeri történésnek, hanem újból és újból fellángolva, tartós módon az emberiség hétköznapjainak részét fogja képezni a belátható jövőben is. Nem mondhatjuk ki azt, hogy az Olaszországban megtapasztalt katasztrófahelyzet többé nem ismétlődhet, és a besorolás morális terhe többé már nem fogja nyomni a döntéshozatalra kényszerülő orvostársadalom vállát.

A SIAARTI ajánlásainak szerzői felvállalták annak a kijelentésnek a terhét, miszerint még a fejlett és gazdag országokban is számolni kell azzal a lehetőséggel, hogy az intenzív terápiás osztályok nem lesznek képesek a szükséges ellátásban részesíteni számos rászorulót. Ha az igények és a rendelkezésre álló erőforrások között kivételes aránytalanság mutatkozik, a szerzők úgy vélekednek, hogy az elosztásban a legnagyobb várható egyéni haszon utilitarista szempontját kell(ene) alkalmazni: tehát az intenzív terápiába való felvételkor elónyt élvezne az a páciens, aki - túlélési esélyét, valamint a kezeléssel megmenthető, várható életévei számát tekintve - a legtöbb hasznot remélheti a kezeléstől. A túlélési esély és a várható életévek kalkulálásában szerepet játszana az adott beteg életkora, esetleges más betegségei, illetve a vírusfertőzést megelőző időszakban fennállt funkcionális státusza. Emellett a szerzők hangsúlyozzák, hogy az egyéniesített orvosi döntéshozatalnak alapvetően klinikai szempontokon kell nyugodnia - ugyanakkor az ajánlások (legnagyobb felháborodást kiváltott) 3. pontja szerint lehetséges, hogy az intenzív terápiás ellátásba történő bebocsátás kapcsán életkori korlátokat lesz szükséges felállítani. A javasolt besorolási szempontrendszernek részét képezné továbbá az is, hogy az adott beteg előreláthatóan milyen hosszú ideig szorulna az intenzív terápiás osztályon történő kezelésre, ez pedig elősegíthetné a 
korlátozott mennyiségben rendelkezésre álló intenzív terápiás erőforrások optimális kihasználását.

A SIAARTI ajánlásainak megjelenése azonnali reakciót váltott ki az olasz orvostársadalom számos tagjából. 2020. március 7-én Filippo Anelli, a FNOMCeO elnöke éles hangú sajtóközleményt [34] adott ki, amelyben kétségbeesett „segélykiáltás”-nak minősítette a dokumentumot, majd leszögezte, hogy az olasz gyógyítási gyakorlatot a jelenleg hatályos, deontológiai alapokon nyugvó orvosetikai kódex irányítja, amely szerint minden beteg egyenlő, és minden beteget diszkriminációtól mentesen kell ellátásban részesíteni. Ha pedig - Anelli szerint valaha is felvetődne annak a gondolata, hogy kényszermegoldásként az eróforrások elosztása során valamiféle besorolás volna szükséges, akkor annak elveit etikai vitákat és elemzéseket követően, a teljes orvosszakma és a társadalom bevonásával szükséges kialakítani. Anelli továbbá kijelentette: nem szabad engedni, hogy a SIAARTI által vizionált helyzet bekövetkezzen, és valaha is a háborús triázs módszereit kelljen alkalmazni az olasz egészségügyben. Március 9-én a geriátria területén múködő egészségügyi szakembereket tömörítő SIGG és SIGOT vezetői nyilatkoztak úgy, hogy az idős betegek feláldozásának gondolata elfogadhatatlan, újabb lélegeztetőgépek beszerzését sürgették, majd leszögezték, hogy egy esetleg mégis bekövetkező szükséghelyzet esetén a betegeket nem pusztán életkoruk szerint, hanem komplex szakmai szempontrendszer alapján kell(ene) besorolni [35]. Március 10-én az ápolókat tömörítő szakmai kamara, a FNOPI adott ki hasonló szellemű közleményt, amelyben kinyilvánították, hogy a gazdasági szempontok sohasem szoríthatják háttérbe az emberi élet védelmének abszolút kötelezettségét [36]. A késóbbi fejlemények sajnálatosan rámutattak azonban arra, hogy ezek az elvárások és értékek az eszkalálódó járványhelyzetben nem tarthatók be maradéktalanul.

E további tapasztalatokat értékesítve a SIAARTI munkacsoportját vezető Marco Vergano és újabb szerzôtársai 2020 júniusában megjelent elemzésükben [37] elismerték, hogy javaslatuk valóban szembemegy az olasz egészségügyben jelenleg elismert és alkalmazott egalitáriánus megközelítéssel, ugyanakkor hangsúlyozták, hogy elkerülhetetlen a besorolás problémájával történő szembenézés. Véleményük szerint egy újabb - SARS-CoV-2 vagy más kórokozó által kiváltott - szükséghelyzet esetén az olyan országokban, ahol a betegek besorolására nézve nincsenek etikai irányelvek és következetesen végigvitt allokációs eljárások, fenn fog állni a méltánytalan döntéshozatal veszélye. Ha az erőforráshiány úgy következik be, hogy az elosztásnak nincsen elfogadott szabályrendszere, a betegek ellátásának sorrendjéról a pillanat hevében a helyi egészségügyi hatóság, a kórházak vezetősége vagy éppen egy klinikus fog határozni, e döntések pedig koordinálatlanok és következetlenek lesznek.

A szerzők úgy vélekednek, hogy ha újból elóállna a 2020 tavaszán bekövetkezett helyzet, a betegek érkezési sorrendben történő ellátása lehetetlen lesz, mivel az erő- források szúkösségének tudatában lévő emberek megrohamoznák a kórházakat, s mindez társadalmi elégedetlenséghez, sôt zavargásokhoz vezetne - ha viszont a klinikusokat etikai támpontok és ajánlások nélkül magukra hagyjuk a betegek besorolásában, mindez könynyen torkollhat szubjektív, esetleg önkényes és méltánytalan döntéshozatalba. Az olasz tapasztalat ugyanakkor azt is egyértelmúvé tette, hogy az orvosok szinte elviselhetetlen morális teherként élték meg, hogy úgymond improvizatív módon kellett eldönteniük, kit kezelnek és kit nem [38, 39]. Az olasz egészségügyi ellátórendszert több szempontból is felkészületlenül érte a pandémia: nemcsak intenzív terápiás ágyból volt kevés, hanem az orvosok és ápolók pszichésen sem voltak felkészülve arra, hogy milyen drámai döntéseket kell majd hozniuk. A SIAARTI ajánlásai ebben a helyzetben születtek azzal a szándékkal, hogy a korábban elképzelhetetlen fizikai és pszichés nyomás alatt álló klinikusoknak valamiféle támpontrendszert nyújtsanak, visszatekintve pedig a szerzők maguk is elismerték, hogy az ajánlások nyilvánosságra hozatalát megelőzően célszerü lett volna egyeztetni a szélesebb szakma és a civil társadalom képviselőivel is, mert mindez nagyobb elfogadottságot eredményezhetett volna.

A SIAARTI ajánlásai nem képesek teljesen megszüntetni az igazságtalan döntés lehetőségét, hiszen - ahogyan ezt a szerzők is hangsúlyozzák - a dokumentumban szereplő szempontok ajánlások, amelyeket rugalmasan, az adott helyzet sajátosságaira való teljes odafigyeléssel lehet(ne) alkalmazni. Tulajdonképpen még az sem elvárás, hogy a SIAARTI ajánlásait bármilyen formában alkalmazzák - a dokumentum azonban mindenképpen alkalmas arra, hogy elindítson egy, az életmentő eszközök igazságos elosztására irányuló szakmai és társadalmi vitát, amelynek megkerülhetetlenségét a COVID-19-pandémia fájdalmasan egyértelmúvé tette.

\section{Következtetések}

Vergano és szerzótársai szerint [37] az olasz tapasztalatok a következő négy pontban sommázhatók: (1) Szükséghelyzetben a betegközpontú ellátás kötelezettsége mellé be kell emelni bizonyos olyan, a köz érdekeire koncentráló szempontokat, amelyek a károk és hasznok társadalmi szinten történő méltányos elosztását tehetik lehetővé. (2) Amikor szükséghelyzetben az egészségügyi erőforrások nem elegendőek az összes rászoruló ellátásához, az érkezési sorrendben történő ellátás elvét nem szabad alkalmazni. (3) Mivel a már bekövetkezett szükséghelyzetben bármiféle etikai ajánlás kidolgozása igen nehéz és politikailag is kényes feladat, az intenzív terápiás ellátásra vonatkozóan előre kell megalkotni bizonyos döntéshozatali szabályokat, beleértve ebbe azt is, hogy a rendelkezésre álló erőforrások igényekhez mért rendkívüli szűkössége esetén hogyan történjen a betegek besorolására vonatkozó döntéshozatal. (4) Az eróforrások allokációjának etikai problémájáról politikai és társadalmi vitát kell 
folytatni, azon prioritások és értékek beazonosítása érdekében, amelyeket a besorolásban alkalmazni lehet. A COVID-19-pandémia számos súlyos tapasztalata közül az egyik az, hogy nem kerülhetjük el a fenti morális kihívással történő szembenézést, és az életmentő orvosi eszközök igazságos elosztásának kérdéséról nyíltan kell beszélnünk - felvállalván még azt a nyomasztó és terhes feladatot is, hogy a korábban megváltoztathatatlannak tekintett értékeket és alapelveket újabb, az aktuális valóság által ránk kényszerített perspektívából kezdjük el szemlélni.

A megélt drámai események hatására a medicina, etika és jog művelőinek nemzetközi közössége is egyre szélesebb körben érzékeli [40], hogy egy esetleges újabb egészségügyi világválság megfelelő kezeléséhez a többség által támogatott, szilárd etikai irányelvekre, valamint az ezen irányelveket következetesen alkalmazó szervezetrendszerre lesz szükség. Az ehhez vezető úton az első lépést az jelentheti, hogy a fentiekben körvonalazott, immár megkerülhetetlennek tünő kérdésekről párbeszédet kezdeményezünk a szakemberek és a teljes társadalom bevonásával.

Anyagi támogatás: A közlemény megírása anyagi támogatásban nem részesült.

A cikk végleges változatát a szerző elolvasta és jóváhagyta.

Érdekeltségek: A szerzőnek nincsenek érdekeltségei.

\section{Irodalom}

[1] WHO Director-General's opening remarks at the media briefing on COVID-19 - 11 March 2020. Available from: https://www. who.int/dg/speeches/detail/who-director-general-s-openingremarks-at-the-media-briefing-on-covid-19---11-march-2020 [accessed: July 15 2020].

[2] Mozsár F. Resource allocation in the health care industry. In: Lengyel I. (ed.) Growth and development of regions: health industrial and knowledge-based development strategies. $[\mathrm{Az}$ egészségügyben felhasznált erőforrások allokációja. In: Lengyel I. (szerk.) Térségek növekedése és fejlődése: egészségipari és tudásalapú fejlesztési stratégiák.] Szegedi Tudományegyetem Gazdaságtudományi Kar, JATEPress, Szeged, 2018; pp. 136150. [Hungarian]

[3] Kovács J. The fundamentals of modern medical ethics. Introduction into bioethics. Second revised edition. [A modern orvosi etika alapjai. Bevezetés a bioetikába. Második, átdolgozott kiadás.] Medicina Könyvkiadó, Budapest, 2006. [Hungarian]

[4] Kilner JF. Who lives? Who dies? Ethical criteria in patient selection. Yale University Press, New Haven, CT, 1990.

[5] Robinson J, Porter M, Montalvo Y, et al. Losing the wait: improving patient cycle time in primary care. BMJ Open Qual. 2020; 9: e000910.

[6] Beauchamp TL, Childress JF. Principles of biomedical ethics. Oxford University Press, Oxford, 1979.

[7] Cookson R, Dolan P. Principles of justice in health care rationing. J Med Ethics 2000; 26: 323-329.

[8] Konow J. Which is the fairest one of all? A positive analysis of justice theories. J Econ Lit. 2003; 41: 1188-1239.
[9] La Puma J, Lawlor EF. Quality-adjusted life-years: ethical impli cations for physicians and policymakers. JAMA 1990; 263: 2917-2921.

[10] Tanyi A, Kollár Zs. Ethics and health care politics. [Etika és egészségpolitika.] DEMOS Magyarország Alapítvány, Budapest, 2008. Available from: https://philarchive.org/archive/ TANESE [accessed: June 8, 2020]. [Hungarian]

[11] Williams A. Intergenerational equity: an exploration of the 'fair innings' argument. Health Econ. 1997; 6: 117-132.

[12] LeGrand J. Equity and choice. Harper Collins, London, 1991.

[13] Mitchell, G. A brief history of triage. Disaster Med Public Health Prep. 2008; 2(Suppl 1): S4-S7.

[14] Spire Ch, Lombardy P. Concise summary of the organising and functioning of the health care services in times of war. Health care principles and tactics. [Précis d'organisation et de fonctionnement du service de santé en temps de guerre. Principes et tactique sanitaire.] Charles-Lavauzelle, Paris, 1925. [French]

[15] Toursarkissian M, Oldenburg D, Benker M. Triage: a military physician's perspective. [Triage - aus militärärztlicher Sicht.] Z Evid Fortbild Qual Gesundh.wesen 2010; 104: 407-410. [German]

[16] Pápai T. The process of patient admission and triage, and nursing competencies in the emergency department. [A betegfogadás és osztályozás folyamata, az ellátás sorrendjének meghatározása és ápolói kompetenciái a Sürgősségi osztályon.] Nővér 2012; 25(1): 5-16. [Hungarian]

[17] Krafft T, Castrillo-Riesgo GL, Edwards S, et al. European Emergency Data Project (EED Project): EMS data-based health surveillance system. Eur J Public Health 2003; 13(Suppl 1): 85-90.

[18] European Emergency Data Project. EMS data-based health surveillance system. Project report. Available from: https://ec. europa.eu/health/ph_projects/2002/monitoring/fp_monitoring_2002_frep_07_en.pdf [accessed: July 17, 2020].

[19] World Health Organization. Regional Office for Europe \& European Union. Emergency medical services systems in the European Union: report of an assessment project co-ordinated by the World Health Organization. WHO Regional Office for Europe, Copenhagen, 2008. Available from: https://apps.who.int/iris/ handle/10665/107916 [accessed: July 15, 2020].

[20] Emergency planning and preparedness. Ontario Health Plan for an Influenza Pandemic 2013. Available from: http://www. health.gov.on.ca/en/pro/programs/emb/pan_flu/pan_flu_ plan.aspx [accessed July 15, 2020].

[21] Christian MD, Hawryluck L, Wax RS, et al. Development of a triage protocol for critical care during an influenza pandemic. CMAJ 2006; 175: 1377-1381.

[22] Winsor S, Bensimon CM, Sibbald R, et al. Identifying prioritization criteria to supplement critical care triage protocols for the allocation of ventilators during a pandemic influenza. Healthe $Q$. 2014; 17: 44-51.

[23] L'Istituto Nazionale per le Malattie Infettive, "Lazzaro Spallanzani", Istituto di Ricovero e Cura a Carattere Scientifico, Direzione Sanitaria. Bollettino medico numero 2 - 1 febbraio 2020. Available from: https://www.inmi.it/wp-content/uploads/ 2020/02/BOLLETTINO-1-FEBBRAIO-1.pdf [accessed: July 15,2020 ]. [Italian]

[24] Covid-19 - Situazione in Italia. Available from: http://www. salute.gov.it/portale/nuovocoronavirus/dettaglioContenutiNuovoCoronavirus.jpp?area $=$ nuovoCoronavirus\&id $=5351$ \&ling ua $=$ italiano\&menu=vuoto [accessed: July 15, 2020]. [Italian]

[25] Ministero della Salute, Direzione generale della programmazione sanitaria. Linee di indirizzo nazionali sul triage intraospedaliero. Available from: http://www.salute.gov.it/imgs/C_17_notizie_3849_listaFile_itemName_1_file.pdf [accessed: July 15, 2020]. [Italian]

[26] Vergano M, Bertolini G, Giannini A, et al. Clinical ethics recommendations for the allocation of intensive care treatments in exceptional, resource-limited circumstances. Italian Society 
of Anaesthesia, Analgesia, Resuscitation and Intensive Care (SIAARTI). [Raccomandazioni di etica clinica per l'ammissione a trattamenti intensivi e per la loro sospensione, in condizioni eccezionali di squilibrio tra necessità e risorse disponibili. Società Italiana di Anestesia Analgesia Rianimazione e Terapia Intensiva (SIAARTI).] 6 March 2020. Available from: http://www.siaarti.it/SiteAssets/News/COVID 19\%20-\%20documenti\%20 SIAARTI/SIAARTI\%20-\%20Covid 19\%20-\%20Raccomandazioni\%20di\%20etica\%20clinica.pdf [accessed: March 22, 2020]. [Italian]

[27] Vergano M, Bertolini G, Giannini A, et al. SIAARTI recommendations for the allocation of intensive care treatments in exceptional, resource-limited circumstances. Minerva Anestesiol. 2020; 86: 469-472.

[28] Vergano M, Bertolini G, Giannini A, et al. Clinical ethics recommendations for the allocation of intensive care treatments in exceptional, resource-limited circumstances: the Italian perspective during the COVID-19 epidemic. Crit Care 2020; 24: 165.

[29] Sentenza 26 giugno 2002, n. 282. Available from: https://www. camera.it/cartellecomuni/leg14/RapportoAttivitaCommissioni/commissioni/allegati/12/12_all_sent2002282.pdf [accessed: July 21, 2020]. [Italian]

[30] Zsák É. How do people of Italy see the right to die? - through the case of Eluana Englaro. [A halálhoz való jog kérdése Olaszországban - Eluana Englaro esete.] Kharón 2014; 18: 42-47. [Hungarian]

[31] Gazzetta Ufficiale Della Repubblica Italiana, Serie generale - n. 12, 16-1-2018, Roma. Available from: https://www.gazzettaufficiale.it/eli/id/2018/1/16/18G00006/sg [accessed: September 3, 2020]. [Italian]

[32] Ciliberti R, Gorini I, Gazzaniga V, et al. The Italian law on informed consent and advance directives: new rules of conduct for the autonomy of doctors and patients in end-of-life care. J Crit Care 2018; 48: 178-182.

[33] Piccinni M, Aprile A, Benciolini P, et al. Ethical, deontological and legal considerations regarding the SIAARTI document titled "Clinical ethics recommendations for admission to and suspension of intensive care in exceptional conditions of imbalance between needs and available resources". [Considerazioni etiche, deontologiche e giuridiche sul Documento SIAARTI "Raccomandazioni di etica clinica per l'ammissione a trattamenti intensivi e per la loro sospensione, in condizioni eccezionali di squilibrio tra necessità e risorse disponibili”.] Recenti Prog Med. 2020; 111: 212-222. [Italian]

[34] Anelli (FNOMCeO) on the Siaarti document: "The Deontological Code shall continue to be our guide". [Anelli (FNOM$\mathrm{CeO}$ ) su documento Siaarti: "Nostra guida resta il Codice deontologico".] FNOMCeO, 7 March 2020. Available from: https://portale.fnomceo.it/anelli-fnomceo-su-documentosiaarti-nostra-guida-resta-il-codice-deontologico/ [accessed: March 22, 2020]. [Italian]

[35] Coronavirus. Geriatrists: "No to the Tarpeian Rock, the solution is not to sacrifice our elderly". [Coronavirus. Geriatri: "No a Rupe Tarpea, la soluzione non è sacrificare gli anziani".] Quotidiano Sanità, 9 March 2020. Available from: https://www. quotidianosanita.it/scienza-e-farmaci/articolo.php?articolo_ id $=82299$ [accessed: March 22, 2020]. [Italian]

[36] Coronavirus. Fnopi on the document of the anaesthetists and reanimators: "The National Health Service should not abandon anybody". [Coronavirus. Fnopi sul documento degli anestesistirianimatori: "Ssn non lasci solo nessuno".] Quotidiano Sanità, 10 March 2020. Available from: https://www.quotidianosanita. it/scienza-e-farmaci/articolo.php?articolo_id=82353 [accessed: March 22, 2020]. [Italian]

[37] Craxì L, Vergano M, Savulescu J, et al. Rationing in a pandemic: lessons from Italy. Asian Bioeth Rev. 2020; 12: 325-330.

[38] Zubek L. Options for the repair of communication and self-determination in the field of end-of-life decisions at intensive care units. [A kommunikáció és az önrendelkezés javításának lehetőségei az életvégi döntések meghozatalánál az intenzív osztályokon.] Orv Hetil. 2016; 157: 669-674. [Hungarian]

[39] Busa Cs, Zeller J, Csikós Á. Who should decide at the end of life? International practice of advance care planning and possibilities for adaptation in Hungary. [Ki döntsön az élet végén? Az ellátás előzetes tervezésének nemzetközi gyakorlata és hazai lehetőségei.] Orv Hetil. 2018; 159: 131-140. [Hungarian]

[40] Ezekiel JE, Persad G, Upshur R, et al. Fair allocation of scarce medical resources in the time of Covid-19. N Engl J Med. 2020; 382: 2049-2055.

(Péter Orsolya Márta dr., Budapest, Nagyvárad tér 4., 1089 e-mail: peter.orsolya@med.semmelweis-univ.hu)

\section{"Ave Caesar, morituri te salutant!" (Suetonius) (Üdvözlégy Caesar, a halálba indulók köszöntenek.)}

A cikk a Creative Commons Attribution 4.0 International License (https://creativecommons.org/licenses/by/4.0/) feltételei szerint publikált Open Access közlemény, melynek szellemében a cikk bármilyen médiumban szabadon felhasználható, megosztható és újraközölhető, feltéve, hogy az eredeti szerző és a közlés helye, illetve a CC License linkje és az esetlegesen végrehajtott módosítások feltüntetésre kerülnek. (SID_1) 